\title{
DESAIN DAN STRUKTUR ORGANISASI
}

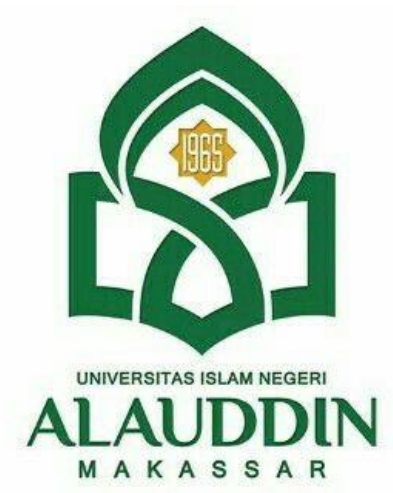

\author{
MAKALAH \\ Diseminarkan Pada Mata Kuliah Pengantar Manajemen Program Studi \\ Perbankan Syariah Semester I Tahun 2021
}

Oleh :

Muh. Irwan Arfin

NIM. 90500121031

Dosen Pengajar:

Dra. Hj. Nuraeni Gani. MM

\section{PROGRAM STUDI PERBANKAN SYARIAH FAKULTAS EKONOMI DAN BISNIS ISLAM UIN ALAUDDIN MAKASSAR 2021}


KATA PENGANTAR

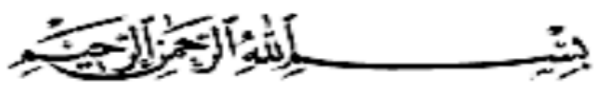

Puji syukur kami panjatkan kehadirat Allah SWT yang telah melimpahkan rahmat, hidayah serta karunia-Nya kepada kami sehingga kami dapat menyelesaikan makalah yang berjudul "DESAIN DAN STRUKTUR ORGANISASI". Tidak lupa kami juga mengucapkan banyak terimakasih atas bantuan dari pihak yang telah berkontribusi dalam penyusunan makalah ini dari awal hingga akhir.

Makalah ini berisikan uraian tentang Desain dan struktur organisasi, khususnya tentang arti penting dari Desain dan struktur organisasi itu sendiri.

Kami menyadari sepenuhnya bahwa makalah ini masih ada kekurangan baik dari segi susunan kalimat maupun tata bahasanya. Oleh karena itu kritik dan saran dari semua pihak yang bersifat membangun selalu kami harapkan demi kesempurnaan makalah ini.

Akhir kata, kami berharap semoga makalah "Desain dan struktur organisasi" ini dapat memberikan manfaat maupun inspirasi terhadap pembaca.

Bulukumba, 11 November 2021

Muh. Irwan Arfin 


\section{DAFTAR ISI}

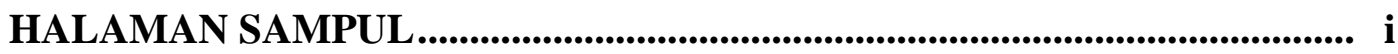

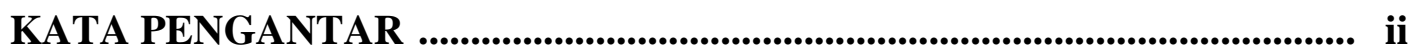

DAFTAR ISI....................................................................................................... iii

BAB I PENDAHULUAN ............................................................................................ 1
A. Latar Belakang ........................................................................... 1
B. Rumusan Masalah ........................................................................ 1

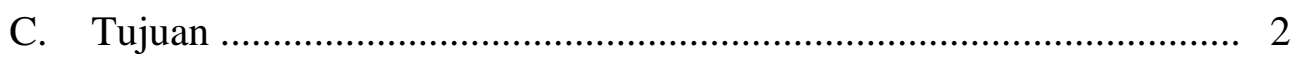

BAB II PEMBAHASAN ............................................................................................. 3

A. Pengertian Struktur Organisasi......................................................... 3

B. Aspek-Aspek penting menentukan efektivitas struktur ............................ 4

C. Pengertian Desain Organisasi ........................................................... 7

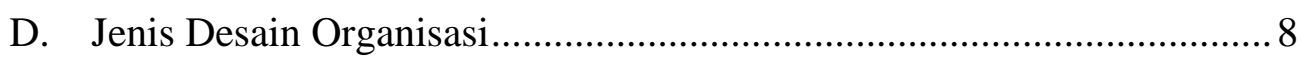

E. Faktor yang mempengaruhi Desain dan Struktur Organisasi ................. 8

BAB III PENUTUP ............................................................................................................ 10
A. Kesimpulan...
10
B. Saran
10

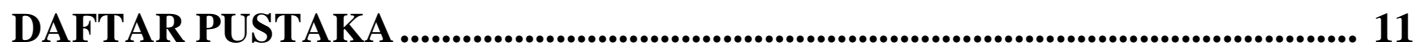




\section{BAB I \\ PENDAHULUAN}

\section{A. Latar Belakang}

Sumber Daya Manusia merupakan faktor yang sangat penting dalam sebuah organisasi baik organisasi dalam skala besar maupun kecil. Dalam organisasi berskala besar, sumber daya manusia dipandang sebagai unsur yang sangat menentukan dalam proses pengembangan usaha peran sumber daya manusia menjadi semakin penting (Tadjudin, 1995). Perkembangan dunia usaha akan terealisasi apabila ditunjang oleh sumber daya manusia yang berkualitas. Desain dan struktur organisasi merupakan salah satu isu dalam manajemen yang masih cukup menarik untuk diperbincangkan hingga dewasa ini. Media massa, baik elektronik maupun cetak, seringkali menampilkan opini dan pembicaraan yang membahas seputar Desain dan struktur organisasi. Peran Desain dan struktur organisasi yang sangat strategis dan penting bagi pencapaian misi, visi dan tujuan suatu organisasi, merupakan salah satu motif yang mendorong manusia untuk selalu menyelidiki seluk-beluk yang terkait dengan Desain dan struktur organisasi.

\section{B. Rumusan Masalah}

Berdasarkan latar belakang yang telah penulis uraikan, maka pokok masalah yang diangkat dalam penelitian ini adalah:

1. Apa pengertian struktur organisasi? 
2. Apa pengertian desain organisasi?

3. Bagaimana konsep dasar pengorganisaisan?

4. Apa faktor yang memengaruhi struktur organisasi

\section{Tujuan}

Berdasarkan latar belakang seperti diatas maka akan timbul beberapa tujuan penelitian sebagai berikut :

1. Memberi pengetahuan seputar Desain dan struktur organisasi

2. Mengetahui defenisi dari Desain dan struktur organisasi

3. Mengetahui tentang implikasi manajerial dalam Desain dan struktur organisasi

4. Memenuhi tugas mata kuliah pengantar manajemen

5. Memberikan ilmu kepada pembaca

6. Untuk menambah wawasan atau pemahaman terhadap pentingnya manajemen straegi dalam perusahaan 


\section{BAB II}

\section{PEMBAHASAN}

\section{A. Pengertian Struktur Organisasi}

Pada dasarnya, Struktur adalah cara sesuatu disusun atau dibangun. Sedangkan organisasi adalah suatu wadah berkumpulnya minimal dua orang untuk mencapai sebuah tujuan.Sehingga, Struktur Organisasi adalah suatu susunan dan hubungan antara tiap bagian baik secara posisi maupun tugas yang ada pada perusahaaan dalam menjalin kegiatan operasional untuk mencapai tujuan.

Struktur adalah hubungan antara macam-macam fungsi atau aktivitas di dalam organisasi. Struktur organisasi adalah hubungan antar para pegawai dan aktivitas-aktivitas mereka satu sama lain serta terhadap keseluruhan, di mana bagian-bagiannya adalah tugas-tugas, pekerjaan-pekerjaan atau fungsi-fungsi dan masing-masing anggota kelompok pegawai yang melaksanakannya.

Struktur organisasi yang akan dibentuk tentunya struktur organisasi yang baik. Struktur organisasi yang baik harus memenuhi syarat sehat dan efisien.Struktur organisasi sehat berarti tiap-tiap satuan organisasi yang ada dapat menjalankan peranannya dengan tertib.Struktur organisasi efisien berarti dalam menjalankan peranannya tersebut masing-masig satuan organisasi dapat mencapai perbandingan terbaik antara usaha dan hasil kerja. 


\section{B. Aspek-Aspek Penting Menentukan Efektivitas Struktur}

Terdapat enam elemen kunci yang perlu diperhatikan oleh para manajer ketika hendak mendesain struktur, antara lain:

1. Spesialisasi Kerja

Pembagian kerja pada akhir abad kedua puluh dan menyimpulkan bahwa pembagian kerja menyebabkan meningkatnya produktivitas karyawan. Sekarang ini kita menggunakan istilah spesialisasi kerja,untuk melukiskan sejauh mana tugas-tugas di organisasi dibagi-bagi menjadi sebuah pekerjaan sendiri.Inti dari pekerjaan spesialisasi adalah bahwa keseluruhan pekerjaan tidak dikerjakan oleh satu orang tapi dipecah menjadi beberapa langkah dan setiap langkah diselesaikan oleh orang yang berbeda.Karyawan individual dispesialisasikan untuk menggunakan sebagian aktifitas bukannya keseluruhan aktivitas pekerjaan.

Kebanyakan menejer zaman sekarang mengganggap spesialisasi kerja sebagai mekanisme pengorganisasian yang penting, tetapi bukan sebagai sumber produktifitas penghematan yang ditimbulkannya dalam beberapa jenis pekerjaan tertentu, tetapi mereka juga menyadari masalah yang ditimbulkan jika spesialisasi itu dilaksanakan terlampau ekstrem.

2. Departementalisasi

Setelah sejumlah pekerjaan dibagi-bagi melalaui spesialisasi kerja, pekerjaan-pekerjaan itu perlu dikelompokkan lagi menjadi satu kelompok yang disebut departemantalisasi. Setiap organisasi akan memiliki cara 
khasnya sendiri dalam mengklasifikasi dan mengelompokkan berbagai kegiatan kerja. Lima bentuk umum Departementalisasi, yaitu:

a) Departementalisasi Fungsional

b) Departementalisasi Produk

c) Departementalisasi Geografis

d) Departementalisasi Proses

e) Departementalisasi Pelanggan

3. Rantai Komando

Merupakan garis wewenang yang tidak terputus yang membentang dari tingkatan atas organisasi hingga tingkatan paling bawah dan menjelaskan siapa melapor kepada siapa.Wewenang merupakan hak yang melekat pada posisi menejerial tertentu yang memberi tahu orang apa yang harus dilakukan dan mengharapkan orang itu melakukannya. Tanggung jawab merupakan kewajiban untuk melaksanakan tugas apa saja yang dibebankan. Kesatuan Komando merupakan prinsip menejemen yang menyatakan bahwa tiap-tiap orang harus melapor kesatu menejer saja.

\section{Rentang Kendali}

Merupakan jumlah karyawan yang dapat dikelola oleh seorang menejer secara efisian dan efektif.Pandangan kontemporer mengenai rentang kendali mengakui bahwa ada banyak faktor yang mempengaruhi jumlah karyawan yang memadai yang dapat dikelola seorang menejer secara 
efisien dan efektif.Faktor itu meliputi keahlian dan kemampuan menejer serta karyawan dan juga sifat pekerjaan yang sedang dikerjakan.

Contohnya, makin banyak latihan dan pengalaman yang dimiliki karyawan, makin sedikit pengawasan langsung yang mereka perlukan.Oleh karena itu, para menejer dengan karyawan yang terlatih dan pengalaman baik dapat berfungsi cukup baik pada rentang yang lebih luas. Variabel kontingensi lainnya yang akan menentukan rentang yang memadai mencakup kasamaan tugas-tugas karyawan, kerumitan tugas itu, jarak fisik dengan bawahan, seberapa besar, prosedur standarisasi yang diterapkan, kecanggihan sistem informasi, informasi organisasi, kekuatan budaya organisasi, dan gaya yang disukai oleh menejer.

5. Sentralisasi dan Desentralisasi

Sentralisasi adalah tingkat dimana pengambilan keputusan terkonsentrasi pada satu titik organisasi. Sedangkan Desentralisasi merupakan tingkat dimana karyawan tingkatan bawah memberikan masukan atau benar-benar mengambil keputusan.

Ketika organisasi menjadi fleksibel dan responsif ada kecenderungan yang khas kearah desentralisasi pengambilan keputusan. Terutama diperusahaan-perusahaan besar, para menejer tingkatan bawah itu lebih dekat dengan tindsakan dan lazimnya mempunyai lebih banyak pengetahuan yang rinci mengenai permasalahan dan cara terbaik untuk memecahkannya dibandingkan para menejer puncak. 


\section{Formalisasi}

Merupakan tingkat dimana pekerjaan dalam organisasi itu dan sejauh mana perilaku karyawan dibimbing oleh peraturan dan prosedur. Derajat formalisasi dapat sangat berbeda-beda antar organisasi dan bahkan didalam organisasi. Misalnya diorganisasi yang menerbitkan koran, para wartawan sering mempunyai banyak keleluasaan atas pekerjaan mereka. Mestikup bisa memilih topik berita mencari berita sendiri, melakukan riset berita menurut cara yang mereka kehendaki, dan menuliskannya, lazimnya dengan pedoman yang minimal. Sebaliknya pegawai tata letak dan tukang set yang menata halaman koran tidak memiliki kebebasan semacam itu. Mereka mempunyai kendala baik waktu maupun ruang yang menstandarisasikan cara mereka menyelesaikan tugasnya.

\section{Pengertian Desain Organisasi}

Menurut para ahli desain organisasi adalah struktur organisasi tertentu sebagai hasil dari berbagai keputusan dan tindakan para (Ivancevich, Konopaske, dan Matteson, 2007:236). 7 Universitas Kristen Petra

1. Desain organisasi adalah keseluruhan rangkaian elemen struktural dan hubungan di antara elemen-elemen tersebut yang digunakan untuk mengelola organisasi secara total (Griffin, 2004:352).

2. Desain organisasi adalah sebuah proses memilih dan mengelola aspekaspek struktural dan kultural yang dilakukan oleh para manajer sehingga organisasi mampu mengendalikan kegiatan apa saja yang perlu dilakukan 
untuk mencapai tujuan bersama (Wisnu dan Nurhasanah, 2005:11). Beberapa pengertian tersebut dapat diketahui bahwa desain organisasi merupakan proses memilih dan mengelola segala aspek-aspek dalam organisasi sehingga menciptakan suatu struktur organisasi tertentu untuk mencapai tujuan bersama.

\section{Jenis Desain Organisasi}

Menurut ( Robbins dan Judge 2008:224) ada tiga desain organisasi yang lazim digunakan, yakni:

a. Struktur Sederhana

Sebuah struktur yang dicirikan dengan kadar departemantalisasi yang rendah, rentang kendali yang luas, wewenang yang terpusat pada seseorang saja, dan sedikit formalisasi. Struktur sederhana paling banyak dipraktikkan dalam usaha-usaha kecil dimana manajer dan pemilik adalah orang yang satu dan sama.

b. Birokrasi Sebuah struktur dengan tugas-tugas operasi yang sangat rutin yang dicapai melalui spesialisasi, aturan dan ketentuan yang sangat formal, tugas-tugas yang 9 Universitas Kristen Petra dikelompokkan ke dalam berbagai departemen fungsional, wewenang terpusat, rentang kendali yang sempit, dan pengambilan keputusan yang mengikuti rantai komando.

c. Struktur Matriks Sebuah struktur yang menciptakan garis wewenang ganda dan menggabungkan departementalisasi fungsional dan produk.

\section{E. Faktor yang mempengaruhi Desain dan Struktur Organisasi}

a. Strategi Organisasi 
Pilihan struktur yang tepat belum menjamin kesuksesan dalam pencapaian tujuan, akan tetapi bisa meningkatkan kemungkinan sukses dalam pencapaian tujuan yang dibutuhkan adalah strategi dalam menjalankan suatu organisasi agar apa yang telah ditetapkan berjalan sesuai dengan yang diinginkan.

b. Skala Organisasi

Skala organisasi dapat dibedakan dari berbagai faktor, diantaranya adalah jumlah penjualan, pangsa pasar, hingga jumlah tenaga kerja. Organisasi yang berskala besar artinya organisasi tersebut memiliki cabang diberbagai daerah dikarenakan pangsa pasarnya yang luas.

c. Teknologi

Faktor teknologi yang dimaksudkan adalah bagaimana suatu produk dari suatu organisasi bisnis dihasilkan atau juga dengan cara bagaimana pekerjaan dilakukan.

d. Lingkungan

Faktor lingkungkan merupakan salah satu yang menentukan bagaimana organisasi akan berjalan. Lingkungan yang dinamis akan menuntut organisasi untuk menyesuaikan diri secara dinamis. 


\section{BAB III}

\section{PENUTUP}

\section{A. Kesimpulan}

Dengan desain organisasi maka keadaan perusahaan bisa terkontrol dan bisa meminimalisir apabila terdapat kendala kedepannya dan bisa memajukan perusahaan untuk bisa menjadi perusahaan yang unggul dibidangnya. Berdasarkan uraian di atas disimpulkan bahwa faktor-faktor yang berpengaruh terhadap komitmen organisasi diantaranya adalah kejujuran dalam pekerjaan, perhatian, kepedulian dan kepercayaan terhadap karyawan, perbedaan karakteristik individu (usia, tingkat pendidikan, jenis kelamin, status perkawinan, karakteristik yang berhubungan dengan pekerjaan, karakteristik struktural (formalitas, desentralisasi), pengalaman dalam kerja, kepercayaan dan penerimaan yang penuh atas nilai-nilai dan tujuan organisasi, keinginan bekerja keras demi kepentingan organisasi, dan keinginan untuk mempertahankan diri agar tetap menjadi anggota organisasi.

\section{B. Saran}

Seorang pemimpin harus mengetahui semua hal yang menyangkut tentang organisasi baik secara individu mau kelompok dan seorang pemimpin membutuhkan support yang kuat di belakangnya sehingga dia bisa menghadapi tantangan bisnis serta kompetisi seberat apapun di depannya. 


\section{DAFTAR PUSTAKA}

- https://martininobel.wordpress.com/perilaku-organisasi/struktur-dan-desainorganisasil

- https://www.slideshare.net/vestersaragih/makalah-bagan-desain-organisasimanajemen

- https://www.slideshare.net/vestersaragih/makalah-bagan-desain-organisasi$\underline{\text { manajemen }}$ 